\title{
The effect of integrating teaching cross-cultural knowledge and teaching listening skill in tertiary education on improving EFL students' intercultural communication competence
}

\author{
Thieu Thi Hoang Oanh ${ }^{1 *}$ \\ ${ }^{1}$ Kien Giang University, Vietnam \\ *Corresponding author: tthoanh@vnkgu.edu.vn
}

\begin{tabular}{|c|c|}
\hline ARTICLE INFO & ABSTRACT \\
\hline $\begin{array}{l}\text { DOI:10.46223/HCMCOUJS. } \\
\text { soci.en.9.1.274.2019 }\end{array}$ & $\begin{array}{l}\text { Teaching cross-cultural knowledge in language teaching is } \\
\text { drawing more and more attention nowadays. This study } \\
\text { investigated the effect of integrating teaching cross-cultural issues } \\
\text { and teaching listening skills on students' intercultural competence. } \\
\text { The participants were } 30 \text { Vietnamese students of English as a } \\
\text { foreign language (EFL) who participated in the course on } \\
\text { Listening } 2 \text { in the second year of their MBA program at Kien } \\
\text { Giang University, Vietnam. The study consisted of an } \\
\text { experimental study based on a pretest-posttest research design on }\end{array}$ \\
\hline Received: April 9 th $^{\text {, }} 2019$ & the integration of cross-cultural issues and teaching listening. The \\
\hline Revised: July $15^{\text {th }}, 2019$ & intercultural sensitivity self-assessment questionnaire (ISSAQ) \\
\hline Accepted: July $17^{\text {th }}, 2019$ & $\begin{array}{l}\text { that serves as a pre-test at the beginning of the semester is based } \\
\text { on the theoretical framework put forth by Bennett and Bennett } \\
\text { (2004). It is to elicit a self-assessment of their intercultural } \\
\text { knowledge, behaviors and attitudes. During the ten-week } \\
\text { intervention, besides helping students master the language and } \\
\text { listening skills, the researcher helped promote students' cross- } \\
\text { cultural competence with the process-oriented intercultural } \\
\text { teaching mode by Liu (2016). At the end of the course, the posttest }\end{array}$ \\
\hline $\begin{array}{l}\text { Keywords: } \\
\text { cross-cultural knowledge, } \\
\text { EFL students, Integrate, } \\
\text { listening skill }\end{array}$ & $\begin{array}{l}\text { was given to measure the effects of the integration model on } \\
\text { students' intercultural communication competence. The results of } \\
\text { the study suggested that integrating cross-cultural knowledge and } \\
\text { language teaching could improve EFL students' intercultural } \\
\text { communication competence (ICC). }\end{array}$ \\
\hline
\end{tabular}

\section{Introduction}

Culture teaching in English teaching is drawing more and more attention. The purpose of learning a foreign language is to learn to communicate in the target language (Sun, 2013). Culture teaching in foreign language education is a problem encountered by language teachers throughout all universities and colleges in the world. The basic goal of learning a foreign language is to acquire communicative competence, while the development and improvement of such competence are to some extent dependent on an efficient and scientific teaching approach. 
One of the important goals of English teaching is to cultivate students' English communication competence. In order to enable the students to use English appropriately, it is necessary to let them learn some necessary knowledge about English culture. In English teaching, culture teaching should be combined with language teaching to help achieve the goal of improving students' communication competence. Necessary culture education will make them understand the difference between their own and English cultures and cultivate their civic awareness, which is important to help form healthy cross-cultural awareness (Chen, 2015).

\section{Defining culture and intercultural communication competence}

Moran (2001) said that culture is "dynamic construction between and among people lying at the crossroads of a number of fields of study and academic disciplines (anthropology, sociology, sociolinguistics, communication theory, intercultural communication, multicultural education, critical pedagogy, cultural studies, ethnic studies, history and semiotics" (pp. 4-5). Culture means personality, how people express themselves (including shows of emotion), the way they think, how they move, how problems are solved, how their cities are planned and laid out, how transportation systems function and are organized, as well as how economic and government systems are put together and function."

With Shi-xu (2006, p. 316), culture is perceived as a group's “way of making meaning through symbolic means".

Kramsch (1993) defined intercultural communication competence as the ability to cross-cultural communication is individual has the intrinsic ability, able to handle the key problems in cross-cultural communication, such as cultural differences strangeness, this cultural attitude within groups, and the resulting psychological pressure, etc. That is to say, students should be paid attention to during the process of learning a foreign so that they can use the language form and the communication method containing information about the social culture and so on.

\section{Necessity for culture teaching in English teaching}

Linguistic competence alone is not enough for learners of a language to master that language. Cultural competence is indisputably an integral part of foreign language learning (Lin, Gu, \& Lu, 1990). It is a goal for teachers to incorporate the teaching of culture into English curriculum. Teachers should teach both language knowledge and cultural knowledge. Teaching of cultural knowledge should be combined with the teaching of language points, language structure and background knowledge, etc. This could help students grasp the standard of their language and behavior during language usage and understand native speakers' thinking mode, etc. All these would encourage students to observe the cultural difference between different languages.

Over the last few decades, a rich understanding of the relationship between language and culture has emerged. The relationship is both interactive and mutually dependent (Bush, 2007). Language denotes culture and culture are realized through. It is through the use of language that people are able to approach and understand the intangible values, beliefs, perspectives, and thoughts that frame the culture shared by a community. When we consider language as communication, language cannot be separated from the cultural frame of reference in which communication takes place. It is, therefore, necessary and important to integrate cultural teaching in foreign language education. 


\section{Contents of culture teaching in English teaching}

Chen (2015) suggested the following aspects to combine culture teaching into English teaching: geography, living environment and lifestyle; historical culture; people and institutions; religious belief; art, literature, music and so on. The following activities are provided: adopting role-play; establishing target culture atmosphere; exposure to the target culture; organizing activities; and guiding students in reading.

Meanwhile, Liang (2014) stated that culture teaching refers to students in cross-cultural, native culture and foreign culture in the teaching activities, guides the student to gain knowledge of cross-cultural, develop respect, tolerance, equality, open cross-cultural psychology and objective, unbiased cross-cultural concept and consciousness of the world, and forms the effective cross-cultural communication, understanding, cooperation and communication ability.

\section{Culture teaching in second language or foreign language education}

\section{Global context}

Culture has long been a focus of discussion by second and foreign language educators and researchers. Many countries, such as Canada, Australia, the United States of America, and some European countries, have a diverse cultural population that prompts the need for intercultural understanding and communication. To promote mutual respect and understanding in the multicultural society, some countries have required L2 educators and curriculum planners to bring tolerance and understanding through language teaching (Larzen-Ostermark, 2008). Teaching intercultural competence is highly valued in this respect. Researchers urge that L2 teaching pedagogy expand the traditional communicative approach to include the acquisition of intercultural competence (Byram, 1997; Crozet, Liddicoat, \& Bianco, 1999).

\section{Local Vietnamese contexts}

Ho's study (2011) investigated the presence and status of cultural content in teaching English as a foreign language (EFL) and the effect of intercultural language learning on learners' EFL learning. The results showed that most respondents 'sometimes' and 'rarely' engage in so-called ICC activities in English classroom.

In Vietnam, teaching culture and teaching English language skills has not been integrated introduced Tran and Duong (2015). ICC has been implied to play a less predominant role in Vietnamese English language teaching curriculum (Ho, 2011; Ho, 2014; Nguyen, 2013).

Vo (2017) investigated English lecturers' perceptions of intercultural communication competence (ICC) in English language teaching in six Vietnamese southern universities. Nearly all of the participants agree with developing ICC through developing their understandings of other cultures via learning or using English language (94\%) but there was still a gap between lecturers' perspectives and practices in ICC teaching. They confront certain inhibiting factors with regard to time allowance, lecturers' cultural knowledge, and English speaking environment.

This partially leads to the fact that Vietnamese students of English may master English in terms of its grammar and linguistics (Nguyen, 2013), but concentrate less on intercultural communication. 


\section{The methods and ways to cultivate English intercultural communication competence}

Liddicoat and Crozet's (2001) model for intercultural language learning/teaching consist of four steps: (1) awareness raising (the stage where learners are introduced to new linguistic and cultural input); (2) experimentation (the stage to help fix learners' newly acquired knowledge via experienced learning); (3) production (the stage of applying in real-life situations and feedback); and (4) feedback (the stage of reflecting on the experience of acting like a native speaker in the production phase and allowing students to discover their place between their first language and culture and their second).

Corbett (2003) stated that standard activities to engage students actively in the target culture and language can be role plays, reading activities, listening activities, writing activities, discussion activities, and even singing. All such activities and materials should be chosen to portray different aspects of culture, highlighting attractive aspects vs. shocking ones, similarities vs. differences, and so on.

Sun (2013) suggested some ways of intercultural communication competence training including changing of teaching concept, changing of teaching method, the introduction of background knowledge of different culture in class, cultivation of non-verbal communication ability, and using physical objects and pictures. Liang (2014) introduced some ways to cultivate English cross-cultural consciousness such as introducing relevant cultural background knowledge, using the appropriate visual image as means of culture teaching, and organizing activities to help students understand the culture of the English-speaking countries and experience to learn knowledge and understanding of English culture, cultural differences.

In his action research in Poland, Piatkowska (2014) used four techniques of social constructivist teaching (namely collaborative learning, situated learning, anchored instruction, and problem solving) to foster foreign language teacher's ability to teach intercultural communicative competence. The results of the study demonstrated that social constructivist techniques can be used to develop learners' ability to construct knowledge and cultural understanding in a foreign language classroom.

Liu (2016) suggested some principles and approaches for cultivating intercultural awareness in English teaching. The principles include the principle of practicality (cultural knowledge that is closely related to their daily life); the principle of "step by step" (teaching should be adjusted according to students' cognitive ability and real language proficiency); the principle of suitability (harmonious and organic combination of both language skills teaching and culture teaching; and the principle of "student-oriented" (teachers are no longer the dominator of the class but the facilitator of the students).

Liu (2016) proposed a process-oriented intercultural teaching mode for promoting students' intercultural communicative competence. It consists of three parts:

(1) Experiencing cultures authentically: students are encouraged to be immersed in the natural cultural setting through the use of a variety of authentic materials. They are inspired to identify the cultural issues with their own life experience based on the topics of the textbook.

(2) Exploring cultures comparatively: This emphasizes the personal involvement and immersion in cultural issues of their country as well as English speaking countries. Exploring cultures comparatively is a crucial part in helping students to present research questions after 
reading research-based materials and form their own independent perception.

(3) Rethinking cultures critically: Its purpose is to encourage students to break or modify the cultural stereotypes and correct or intensify their understanding of western and their own cultures after reflection and interaction based on the peer and teacher assessment.

In this study, the researcher followed this process-oriented intercultural teaching mode to help students get immersed in cross-cultural issues, explore cultures and break their cultural stereotypes because it best helps cultivate students' intercultural communication competence. The research question in the study is as the following:

Does integrating cross-cultural knowledge and teaching listening skills promote students' intercultural communication competence?

Data from the pre/post-test helped give information about the effectiveness of integrating teaching cross-culture knowledge and teaching listening.

\section{Research methodology}

\section{Research aims}

This research aims at focusing on cultural knowledge and enhancing students' intercultural communication.

\section{The participants}

The sample of the study was 30 English major students, aged between 19 and 26, attending the course on Listening 2 of the Faculty of Foreign Languages, Kien Giang University in Vietnam. The students' EFL competence level was identified as A1 - A2 according to the CEFR (Common European Framework of Reference for Languages).

\section{Materials}

Materials and contents should be employed in order to make learners compare and contrast foreign cultures with their own. The present study resorted the coursebook Tactics for Listening (Developing) second edition by Richards, Oxford University Press, 2005.

The book provides good examples of materials/contents that provide plenty of opportunities for learners to examine other cultures and their own from a "third place" perspective.

\section{Design and procedures}

Pre-test

The intercultural sensitivity self-assessment questionnaire (ISSAQ) that serves as a pretest at the beginning of the semester is based on the theoretical framework put forth by Bennett and Bennett (2004). It is to elicit a self-assessment of their intercultural knowledge, behaviors and attitudes.

The questionnaire consists of 20 items to measure the participants' ICC. The participants are informed that if he/she has not experienced a given scenario in real life, imagine how he/she would react in a hypothetical situation.

The first six items ask the participants to circle the most appropriate option (1 Completely Disagree, 2 Disagree, 3 Neutral, 4 Agree, 5 Completely Agree). The next seven 
items require the participants to self-evaluate their ICC. The answer scale for their answer is 1 Not well at all, 2 Minimally, 3 Somewhat, 4 Well, 5 Very Well. The last seven items are multiple questions with five options and ask the participants to select the most appropriate answer.

Cultural lessons (10 weeks)

A process-oriented intercultural teaching mode by Liu (2016) is used to promote students' intercultural communicative competence. It includes three parts: experiencing cultures authentically, exploring cultures comparatively and rethinking cultures critically.

The activities used are group/pair work discussion, role play, comparison, quizzes, movies, photos, guest speakers...

\section{Post-test}

To measure the effects that the cross-cultural information during classroom time may have on individual's levels of intercultural competence, the data is collected once more with the intercultural sensitivity self-assessment questionnaire at the end of the semester. However, in the post-test, there is an additional open-ended question to help the researcher gain more information about the participants' attitudes towards the use of the

ICC integration program. Here is the content of the ISSAQ questionnaire (pre/post-test) and the scoring key for the pre-test and post-test.

Please circle the most appropriate statement. If you have not experienced a given scenario in real life, imagine how you would react in a hypothetical situation.

Answer Scale:

1 Completely Disagree 2 Disagree $\quad 3$ Neutral 4 Agree 5 Completely Agree

\begin{tabular}{|c|l|c|c|c|c|}
\hline \multirow{2}{*}{ Items } & \multicolumn{1}{|c|}{ Statements } & \multicolumn{1}{|c|}{ Options } \\
\cline { 3 - 5 } & \multicolumn{1}{|c|}{$\begin{array}{l}\text { When in an unfamiliar environment I tend to form friendships } \\
\text { quickly. }\end{array}$} & $\mathbf{2}$ & $\mathbf{3}$ & $\mathbf{4}$ & $\mathbf{5}$ \\
\hline 2 & $\begin{array}{l}\text { I am good at problem-solving under pressure or/and in an } \\
\text { unfamiliar setting. }\end{array}$ & & & & \\
\hline 3 & I know which city is the capital of Britain. & & & & \\
\hline 4 & $\begin{array}{l}\text { When I learn about others and their ways of life, I do and have } \\
\text { compared it with my own (way of life) }\end{array}$ & & & & \\
\hline 5 & $\begin{array}{l}\text { I am confident that I could interact in another culture drastically } \\
\text { different than my own. }\end{array}$ & & & & \\
\hline 6 & $\begin{array}{l}\text { I tend to surround myself by people with values and beliefs } \\
\text { similar to my own. }\end{array}$ & & & \\
\hline
\end{tabular}

Answer the following questions to the best of your ability. If you have not experienced a given scenario in real life, imagine how you would react in a hypothetical situation. 
Answer Scale:

1 Not well at all

2 Minimally

3 Somewhat

4 Well

5 Very Well

\begin{tabular}{|c|c|c|c|c|c|c|}
\hline \multirow{2}{*}{ Items } & \multirow{2}{*}{ Statements } & \multicolumn{5}{|c|}{ Options } \\
\hline & & 1 & 2 & 3 & 4 & 5 \\
\hline 7 & $\begin{array}{l}\text { When struggling to learn something new, how well do } \\
\text { you cope with slow progress? }\end{array}$ & & & & & \\
\hline 8 & $\begin{array}{l}\text { How would you assess your curiosity of a foreign } \\
\text { culture vs your own culture? }\end{array}$ & & & & & \\
\hline 9 & $\begin{array}{l}\text { How well do you believe you could adapt to cultural } \\
\text { norms different than your own? }\end{array}$ & & & & & \\
\hline 10 & $\begin{array}{l}\text { How well do you know and understand your own } \\
\text { cultural heritage? }\end{array}$ & & & & & \\
\hline 11 & $\begin{array}{l}\text { How well do you know and understand the other } \\
\text { countries' cultures? }\end{array}$ & & & & & \\
\hline 12 & $\begin{array}{l}\text { How well do you manage stress in an unfamiliar } \\
\text { situation? }\end{array}$ & & & & & \\
\hline 13 & $\begin{array}{l}\text { How well can you form relationships with people who } \\
\text { hold different political views? }\end{array}$ & & & & & \\
\hline
\end{tabular}

Select the most appropriate answer to the remaining questions. If you have not experienced a given scenario in real life, imagine how you would react in a hypothetical situation.

\begin{tabular}{|c|l|}
\hline \multirow{3}{*}{ Items } & \multicolumn{1}{c|}{ Statements } \\
\hline \multirow{5}{*}{14} & $\begin{array}{l}\text { When I find myself in an unfamiliar environment, I } \\
\text { 2) struggle to cope } \\
\text { 3) obtain the necessary results with some misunderstandings } \\
\text { 4) deal with situation with ease } \\
\text { 5) feel calm and confident }\end{array}$ \\
\hline \multirow{5}{*}{15} & $\begin{array}{l}\text { When in a foreign (unfamiliar) environment, I feel I can } \\
\text { 1) got obtain any necessary information and fully rely on help of others } \\
\text { 3) struggle but find my way around if needed } \\
\text { 4) navigate pretty well } \\
\text { 5) obtain all information needed with ease }\end{array}$ \\
\hline \multirow{5}{*}{16} & $\begin{array}{l}\text { When unsure of how to pay my restaurant bill in a different country, I would } \\
\text { 1) speak English and act as I do at home } \\
\text { 2) take a guess about what might be appropriate and act } \\
\text { 3) observe how others are accomplishing the task } \\
\text { 4) ask another patron for help }\end{array}$ \\
\hline
\end{tabular}




\begin{tabular}{|c|c|}
\hline Items & Statements \\
\hline & 5) ask the waitress for help \\
\hline 17 & $\begin{array}{l}\text { When there is no clear indication of which way to go (applicable to any } \\
\text { hypothetical } \\
\text { situation), I tend to } \\
\text { 1) feel very frustrated } \\
\text { 2) may get frustrated } \\
\text { 3) feel certain I can figure it out with the help of others } \\
\text { 4) feel certain I can figure it out by watching others } \\
\text { 5) feel certain I can figure it out on my own }\end{array}$ \\
\hline 18 & $\begin{array}{l}\text { When I encounter a person with a different set of values and beliefs, I would } \\
\text { 1) openly voice my disagreement } \\
\text { 2) not say anything but still disagree } \\
\text { 3) acknowledge his/her perspective but stay true to my convictions } \\
\text { 4) show curiosity to learn more about his/her perspective } \\
\text { 5) eagerly embrace his/her perspective even if it differs from my own }\end{array}$ \\
\hline 19 & $\begin{array}{l}\text { When interacting with a person from another culture who spoke English, I } \\
\text { feel I could convey my ideas } \\
\text { 1) not without some help } \\
\text { 2) without help but with some difficulty } \\
\text { 3) sufficiently and without any help } \\
\text { 4) rather well and without any help } \\
\text { 5) without any problems }\end{array}$ \\
\hline 20 & $\begin{array}{l}\text { A friend of yours is visiting one of the Arabic nations and is unsure whether } \\
\text { she should wear a headscarf. She is not Muslim. You recommend: } \\
\text { 1) she should never wear a headscarf since she is not a part of this culture } \\
\text { 2) she should not wear it unless she is in a formal/religious setting } \\
\text { 3) she should carry a headscarf and wear it if asked even if it conflicts with } \\
\text { her personal beliefs } \\
\text { 4) she should wear it always when she is in public } \\
\text { 5) she should wear a headscarf at all times during her stay }\end{array}$ \\
\hline
\end{tabular}

21. What do you think about the effectiveness of the integration of teaching crossculture issues in teaching listening skills?

Scoring key for pre-test and post-test

\begin{tabular}{|c|c|}
\hline Scores & Option \\
\hline 0 & 1 \\
\hline 0.5 & 2 \\
\hline 1.0 & 3 \\
\hline
\end{tabular}




\begin{tabular}{|c|c|}
\hline Scores & Option \\
\hline 1.5 & 4 \\
\hline 2.0 & 5 \\
\hline
\end{tabular}

The Activities Incorporated in the Lessons for presenting cultural content, the researcher based on the process-oriented intercultural teaching model developed by Liu (2016) to help students get immersed in cross-cultural issues, explore cultures and break their cultural stereotypes. How I addressed culture can be grouped into the following:

(1) In the stage of experiencing cultures, theme-related materials including videos like movie clips, quizzes were given in order to provide students with the opportunity to observe and experience the authentic cultural contexts. The teacher provided cultural information about or explained the cultural point introduced in the teaching materials, or asking students to search for information about it;

(2) In the second phase, the students explore the cultures and make a comparison of Vietnamese and other cultures. Students are encouraged to use different approaches to form their opinions and insights with a variety of perspectives through personal involvement and keen observation. They might find information on some websites or conduct online questionnaires or interviews with Americans;

(3) In the reflection stage, students gave oral presentations in class, and the rest of the students brainstormed and discussed in class. The stage of rethinking cultures was to encourage students to break or modify the cultural stereotypes and correct or intensify their understanding of other cultures and their own cultures.

The activities used are as the following.

\section{- Authentic text}

I addressed culture when a cultural point (e.g., vocabulary items that needed a cultural explanation, cultural behavior or practices) appeared in their teaching materials in a specific class. When lecturing some language materials, I could introduce some related cultural contents, such as historical events, cultural customs, famous places and people, origins of words and expressions and so on. For instance, in the multiple choice listening exercise about a city tour (unit 19), the options were about some stars' houses such as Marilyn Monroe, Jame Deans, Joe DiMaggio and some famous places like the Empire State Building, the Statue of Liberty, Rockefeller Center. I used images, photos and explanations to help the students understand the cultural knowledge better. Those cultural contents added may exert a subtle effect on the learning of both culture and language.

I also provided authentic materials from other countries and asked the students to compare these cultures with their own country's culture. In lesson 12 (Small Talk), students cultivated their cross-cultural awareness through authentic texts. The task helped learners to figure out the similarities and differences in a small talk between western countries and in Vietnam with reference to topics and questions.

\section{Quizzes}

I might ask the students to match each of the introduced vocabulary items with its corresponding picture or explanation printed in the materials (e.g., potluck dinner, buffet, barbecue, birthday party, surprise party - unit 11). It could help the students understand cultural 
knowledge better and make teaching more successful and efficient.

\section{Guest speakers}

Experts or foreign teachers were invited to have presentations on certain topics related to culture or cross-cultural communication. For example, with the topic 'City Transportation' (unit 2), an American teacher brought in an interesting presentation about some common means of transportation in the U.S with the support of photos, video clips and explanations. During his presentation, students have introduced some transportation means that were uncommon in Vietnam such as subway, trams... The students were asked about the means of transportation in Vietnam and they could figure out the similarities and differences between the transportation means in Vietnam and the U.S.

\section{- Role-play}

I often asked my students to practice certain cultural situations in other countries. When organizing class activities, I created a certain social and cultural situation according to the teaching materials and required students to play roles. In unit 11 (Invitations), the tasks focused on acquainting learners with some expressions for inviting and accepting or refusing an invitation. Students also listened to invitations on some people's voicemail. Afterward, students were asked to do role-play activities in which they would invite their friends to watch a baseball game, go to a theatre or go for lunch, and their friends would accept or refuse the invitations using the expressions provided. It was a good way to help students understand the culture as well as practice their language.

\section{TV and movies}

TV and movies via video can offer the visual information that cannot be shown in books. In unit 16 (Movies), students got some insights into different types of movies including western, comedy, horror, action, science fiction, romance, ...through authentic films. The films helped connect learners with language and cultural issues closely.

\section{- Photos/images}

I also resorted to photos and images as a supportive source to explain cultural notes. With the topic 'Hobbies and Pastimes' (unit 13), the coursebook provides photos of leisure activities and suggests a task which requires learners to order the photos according to the listening text. Through photos and explanations, students were introduced to some of the Americans' interests including skiing, hiking, bird watching, playing baseball, gardening, playing in a band, collecting things... This could arouse students' interest in cultural learning and the information was also very useful for the listening multiple-choice and ordering exercises in the lesson.

- Comparison, group/pair work discussion Students were asked to look for other cultural sources of information and compare with their own country's culture. Common activities were presentations about cultural differences between the western countries and Vietnam in terms of things to do at parties, the use of telephones, topics in small talk, eating habits considered to be rude, how to behave during dinner in someone's family, tables manners, and etiquette for visitors (units 11,12,18) and talking about restaurants in Thailand, Japan, Mexico, China, Korea, Vietnam (unit 5). Asking students to look for perspectives of people from other countries on certain topics is shown to be one of the ICC activities in English classrooms (Vo, 2017). I asked the students to look for information about other countries and 
have a group presentation and then elicited comments from the rest of the class then asked them to compare restaurants of many countries in the world. Through photos and explanations in group presentations, students could know some ethnic foods such as burgers, pizza, spaghetti, fries and the custom or leaving tips at restaurants. This helped them a lot when they do multiple choice and matching exercises later in the unit.

\section{Instrument}

The instrument used in the study was pre-test and post-test. The pre-test was also used as the post-test. The test consisted of 20 items and was constructed to measure the students' intercultural communication competence.

\section{Data analysis}

To be reliable, the pre-test and post-test papers were all marked independently by the researcher as well as by two experienced language educators. Items were scored according to the criteria set in the scoring key on a 0-2 points scale, for a maximum score of 40 points per test.

\section{Research results}

The data collected from the students' answers were subjected to the SPSS program to test reliability and frequency. The reliability coefficient for the pre-test was $\alpha=.88, \mathrm{SD}=8.24$; and that for the post-test was $\alpha=.83, \mathrm{SD}=7.83$. This showed that the pre-test and the post-test on students' intercultural competence were reliable. The reliability of the pretest and the posttest is presented as the following.

\section{Table 1}

Reliability of the pre-test

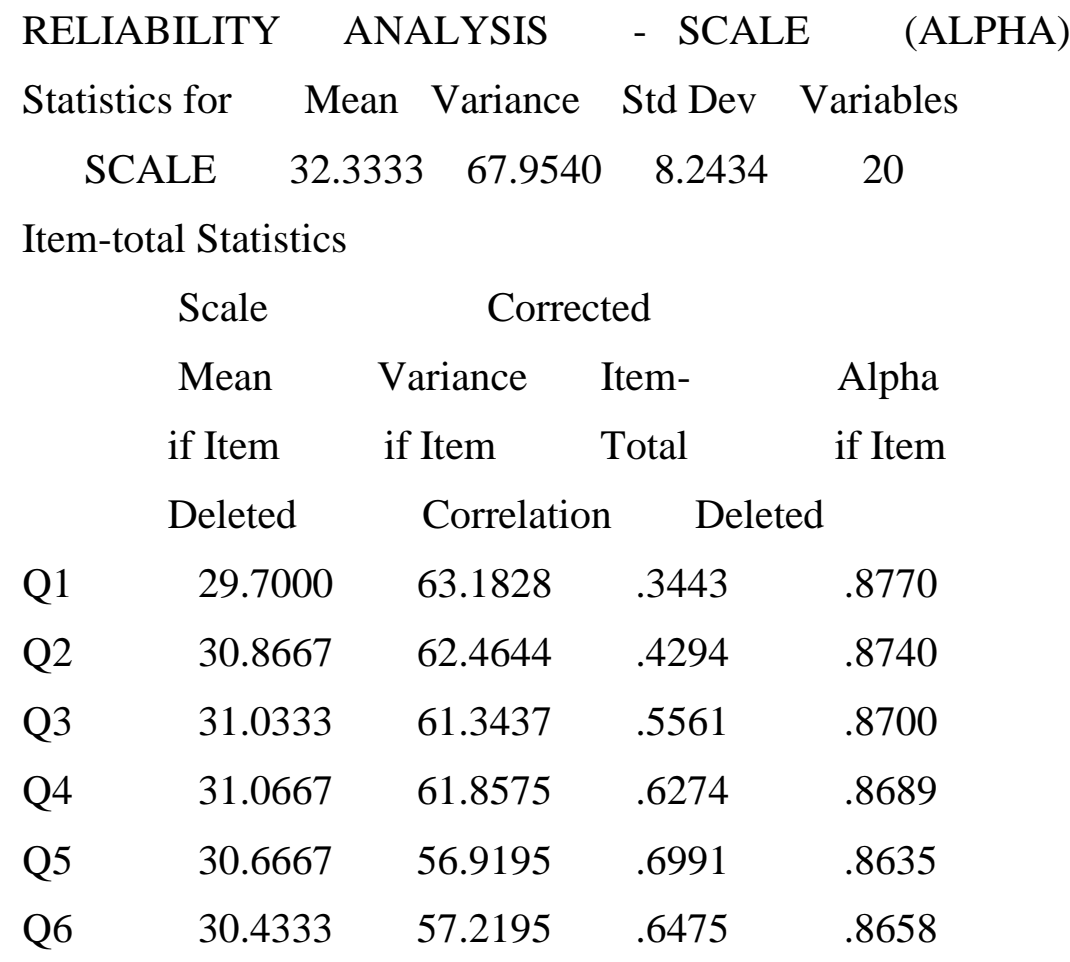




$\begin{array}{lcccc}\text { Q7 } & 30.4667 & 57.5678 & .6126 & .8674 \\ \text { Q8 } & 31.0000 & 60.4828 & .5849 & .8688 \\ \text { Q9 } & 30.9667 & 60.7920 & .5514 & .8699 \\ \text { Q10 } & 31.1000 & 66.4379 & .1536 & .8804 \\ \text { Q11 } & 29.6667 & 63.7471 & .3000 & .8784 \\ \text { Q12 } & 31.3000 & 66.9069 & .3394 & .8782 \\ \text { Q13 } & 29.9667 & 59.5506 & .5267 & .8709 \\ \text { Q14 } & 31.2000 & 63.2000 & .5573 & .8715 \\ \text { Q15 } & 30.5000 & 64.1897 & .2474 & .8804 \\ \text { Q16 } & 31.0000 & 59.3793 & .7362 & .8641 \\ \text { Q17 } & 30.8333 & 60.0747 & .6481 & .8668 \\ \text { Q18 } & 30.8333 & 63.3851 & .2792 & .8801 \\ \text { Q19 } & 30.8000 & 65.6138 & .2534 & .8783 \\ \text { Q20 } & 30.9333 & 60.1333 & .6051 & .8680\end{array}$

Reliability Coefficients

$\mathrm{N}$ of Cases $=30.0 \quad \mathrm{~N}$ of Items $=20$

Alpha $=.8780$

Source: Data analysis result of the research

\section{Table 2}

Reliability of the post-test

RELIABILITY ANALYSIS - SCALE (ALPHA)

Statistics for Mean Variance Std Dev Variables

$\begin{array}{lllll}\text { SCALE } & 38.9667 & 61.3437 & 7.8322 & 20\end{array}$

Item-total Statistics

\begin{tabular}{|c|c|c|c|c|}
\hline & Scale & Correc & cted & \\
\hline & Mean & Variance & Item- & Alpha \\
\hline & if Item & if Item & Total & if Item \\
\hline & Deleted & Correlatio & Dele & \\
\hline QU1 & 36.0333 & 60.1023 & .1957 & .8275 \\
\hline QU2 & 37.0000 & 56.4138 & .3294 & .8236 \\
\hline QU3 & 37.4333 & 55.4264 & .4300 & .8185 \\
\hline U4 & 37.3333 & 52.1609 & .6528 & .8061 \\
\hline
\end{tabular}




$\begin{array}{lcccc}\text { QU5 } & 36.8000 & 52.8552 & .5246 & .8130 \\ \text { QU6 } & 36.3333 & 55.1954 & .4895 & .8159 \\ \text { QU7 } & 36.8333 & 53.8678 & .4366 & .8184 \\ \text { QU8 } & 37.3333 & 52.7126 & .5767 & .8101 \\ \text { QU9 } & 37.5667 & 53.7023 & .5852 & .8107 \\ \text { QU10 } & 37.4667 & 56.2575 & .3364 & .8233 \\ \text { QU11 } & 36.1333 & 59.2920 & .2166 & .8270 \\ \text { QU12 } & 37.7000 & 58.3552 & .2376 & .8269 \\ \text { QU13 } & 36.1333 & 58.6023 & .3027 & .8243 \\ \text { QU14 } & 37.1667 & 53.4540 & .4733 & .8161 \\ \text { QU15 } & 36.9000 & 58.3000 & .2025 & .8292 \\ \text { QU16 } & 37.3667 & 55.8264 & .3529 & .8226 \\ \text { QU17 } & 37.3000 & 58.0793 & .3133 & .8238 \\ \text { QU18 } & 37.0667 & 54.2023 & .4403 & .8180 \\ \text { QU19 } & 37.1667 & 61.5920 & -.0638 & .8359 \\ \text { QU20 } & 37.3000 & 50.9069 & .6955 & .8026\end{array}$

Reliability Coefficients

$\mathrm{N}$ of Cases $=30.0 \quad \mathrm{~N}$ of Items $=20$

Alpha $=.8275$

Source: Data analysis result of the research

The results showed that almost all students achieved greater gain in competence in the post-test over pre-test. The mean difference between the pre-test and the post-test was 6.63 . The students gained higher scores in the post-test than in the pre-test.

Table 3

Descriptive statistics of the mean performance between the pre-test and the post-test

\begin{tabular}{lcccc}
\hline & Mean & $\begin{array}{c}\text { Standard } \\
\text { Deviation }\end{array}$ & Min-Max & Percentage \\
\hline Pre-test & 12.33 & 8.24 & $1-32$ & $0.31 \%$ \\
Post-test & 18.97 & 7.83 & $8-35$ & $0.47 \%$ \\
$\begin{array}{l}\text { Difference in } \\
\text { mean }\end{array}$ & 6.63 & 3.89 & & \\
\hline
\end{tabular}

Source: The research's data analysis

A GLM (General Linear Model) Repeated Measures test was conducted to check for the difference between the means of the pre-test $(M=12.33, S D=8.24)$ and the post-test $(M=$ 
18.97, $S D=7.83)$.

\section{Table 4}

Test results for the difference between the means of the pre-test and the post-test

\begin{tabular}{cccccccc}
\hline Source & TIME & $\begin{array}{c}\text { Type III } \\
\text { Sum of } \\
\text { Squares }\end{array}$ & df & $\begin{array}{c}\text { Mean } \\
\text { Square }\end{array}$ & F & Sig. & $\begin{array}{c}\text { Partial Eta } \\
\text { Squared }\end{array}$ \\
\hline TIME & Linear & 660.017 & 1 & 660.017 & 87.61 & .000 & .75 \\
Error & Linear & 218.483 & 29 & 7.534 & & & \\
(TIME) & & & & & & & \\
\hline
\end{tabular}

Source: Data analysis result of the research

The results revealed that there was a significant difference in the mean performance between the pre-test and the post-test $(F=87.61, d f=29, p=.000)$. It indicated that the integration of teaching cross-cultural issues and listening skills contributed to the improvement of students' intercultural knowledge; however, the effect size (the level of long effect) was not very high ( $d$ $=.75)$.

A one-sample t-test was conducted on the pre-test scores to evaluate whether their means were the same or different from the average score of the test (20) - the maximum total score for the t-test is 40 . The results were presented as the following.

\section{Table 5}

Mean scores of the pre-test in comparison with the average score

\begin{tabular}{|c|c|c|c|c|c|c|}
\hline & \multicolumn{6}{|c|}{ Test Value $=20$} \\
\hline & $\mathrm{t}$ & $\mathrm{df}$ & $\begin{array}{l}\text { Sig. (2- } \\
\text { tailed) }\end{array}$ & $\begin{array}{l}\text { Mean } \\
\text { Difference }\end{array}$ & $\begin{array}{l}95 \% \mathrm{Cc} \\
\text { of the } \mathrm{D}\end{array}$ & $\begin{array}{l}\text { nce Interval } \\
\text { nce }\end{array}$ \\
\hline PRE & 5.094 & 29 & .000 & 7.67 & $\begin{array}{l}\text { Lower } \\
10.74\end{array}$ & $\begin{array}{l}\text { Upper } \\
4.59\end{array}$ \\
\hline
\end{tabular}

Source: Data analysis result of the research

\section{Table 6}

Mean scores of the post-test in comparison with the average score

\begin{tabular}{|c|c|c|c|c|c|c|}
\hline \multicolumn{7}{|c|}{ Test Value $=20$} \\
\hline & $\mathrm{t}$ & df & $\begin{array}{l}\text { Sig. (2- } \\
\text { tailed) }\end{array}$ & $\begin{array}{l}\text { Mean } \\
\text { Difference }\end{array}$ & $\begin{array}{l}95 \% \mathrm{C} \\
\text { of the }\end{array}$ & $\begin{array}{l}\text { nce Interval } \\
\text { nce }\end{array}$ \\
\hline POST & .723 & 29 & .476 & 1.03 & $\begin{array}{l}\text { Lower } \\
3.96\end{array}$ & $\begin{array}{l}\text { Upper } \\
1.89\end{array}$ \\
\hline
\end{tabular}

Source: Data analysis result of the research 
The mean score of the pre-test $(M=12.33, S D=8.24)$ was different from the average score of the test $(20)(t(30)=5.09, d f=29, \mathrm{p}=.000)$. It can be concluded that the mean score of the pre-test was lower than the average score. It revealed that the mean scores of the posttest $(M=18.97, S D=7.83)$ was the same as $20, t(30)=.72, d f=29, p=.476)$. In other words, the mean score of the post-test was the same as the average score that the test expected. The result indicated that the mean scores increased remarkably from the lower average level in the pre-test to the average level in the post-test. This supported the conclusion that the integration of cross-cultural teaching in listening teaching had a remarkable effect on students' intercultural communication competence.

The additional question in the post-test also helped collect information about students' attitudes towards the implementation of the integration of teaching cross-culture issues in teaching listening skills as well as to evaluate the benefits of what they had learned through the lessons.

Here is the summary of students' responses to the additional question.

1. The programme of integrating cross-cultural knowledge and listening skills helped me improve my intercultural communication competence.

2. I am now more aware of the benefits of cross-culture knowledge in aiding my listening comprehension.

3. I enjoyed learning about cross-cultural issues through listening lessons.

4. I am now more confident in cross-cultural communication with the knowledge I gained from the Program.

5. The programme helped me form healthy cross-cultural awareness.

The data showed that almost all students (96.7\%) agreed that the programme had helped them improve their ICC. $77.7 \%$ of the students thought that they had become more aware of the benefits of cross-culture knowledge in aiding their listening comprehension. $70 \%$ of the students said that they enjoy learning about cross-cultural issues. Over half of the participants (53.4\%) claimed that they were more confident with their cross-cultural communication ability and the majority of the students $(86.7 \%)$ reported that the programme helped them form healthy cross-cultural awareness.

In general, the students had positive thinking about the application of the integration program. They agreed with the benefits of integrating cross-cultural in listening skill teaching.

\section{Conclusion}

Culture must be fully incorporated as a vital component of language. Cultural teaching plays an important role in fulfilling the goal of cultivating cross-cultural communication abilities. The purpose of learning a foreign language is to learn to communicate in the target language, to learn the customs and traditions of the speech community, and to promote one's study and work. However, culture teaching in foreign language education is a problem countered by language teachers throughout all universities and colleges in the world. The development and improvement of such competence need an efficient and scientific teaching approach. 
The research was designed with the purpose to emphasize that English teaching should enable students to function effectively in another language and understand the cultural context, including day-to-day conventions, giving or receiving presents, paying visits, etc. Teachers should identify the relationship between cultural teaching and language teaching and realize the key cultural items in English. They also should try to find out more useful strategies for cultural teaching in the process of English teaching and make use of these different methods to assist their teaching.

One of the study's limitations is related to the representation of the participants to the population. Another limitation of this study relates to the fact that it focuses on measuring the students' ICC from the students' perspectives.

After completing the study, the researcher identified some directions for related studies that would provide greater effectiveness in developing students' ICC. There should be more studies associated with teachers' self-reported cultural teaching practice and fostering foreign language teaches' ability to teach ICC.

\section{References}

Bennett, J. M., \& Bennett, M. J. (2004). Developing intercultural sensitivity: An integrative approach to global and domestic diversity. In D. Landis, J. M. Bennett \& M. J. Bennett (Eds.), Handbook of intercultural training (pp. 147-165). Thousand Oaks, CA: Sage.

Bush, M. D. (2007). Facilitating the integration of culture and vocabulary learning: The categorization and use of pictures in the classroom. Foreign Language Annals, 40 (4), 727-745.

Byram, M. (1997). Teaching and assessing intercultural competence. Clevedon, UK: Multilingual Matters.

Chen, Q. (2015). Culture teaching in English teaching in secondary education. Theory and Practice in Language Studies, 5(11), 2402-2406.

Corbett, J. (2003). An intercultural approach to English language teaching. Clevedon, UK: Multilingual Matters.

Crozet, C., Liddicoat, A. J., \& Bianco, J. L. (1999). Intercultural competence: From language policy to language education. In C. Crozet, A. J. Liddicoat \& J. L. Bianco (Eds), Striving for the third place: Intercultural competence through language education (pp. 1-22). Melbourne, Australia: Language Australia.

Deng, Y., \& Liu, R. (1989). Language and culture: A comparison between English and Chinese. Beijing, China: Foreign Language Teaching and Research Press.

Ho, K. (2011). An intercultural perspective on teaching and learning in the Vietnamese EFL classroom. University of Sydney Papers in TESOL, 6(3), 43-69.

Ho, K. (2014). Implementing intercultural language teaching: A new challenge for foreign language teaching in Vietnam. Journal of Science and Technology of Da Nang University, 6(79), 53-57. 
Kramsch, C. (1993). Context and culture in language teaching. Oxford, UK: Oxford University Press.

Larzen-Ostermark, E. (2008). The intercultural dimension in EFL-teaching: A study of conceptions among Finland-Swedish comprehensive school teachers. Scandinavian Journal of Educational Research, 52(5), 527-547.

Liang, B. (2014). Cross-cultural awareness in college English teaching. Applied Mechanics and Materials, 599-601, 2011-2013. doi:10.4028/www.scientific.net/AMM.599-601.2011

Liddicoat, A. J., \& Crozet, C. (2001). Acquiring French interactional norms through instruction. In K. R. Rose \& G. Kasper (Eds.), Pragmatic development in instructional contexts (pp. 125-144). Cambridge, MA: Cambridge University Press.

Lin, J., Gu, J., \& Lu, S. (1990). Comment on language and culture. Shanghai, China: Shanghai Foreign Language Education Press.

Liu, C. (2016). Cultivation of intercultural awareness in EFL teaching. Journal of Language Teaching and Research, 7(1), 226-232. doi:10.17507/jltr.0701.26

Moran, P. R. (2001). Teaching culture: Perspective in practice. Boston, MA: Heinle \& Heinle.

Nguyen, T. L. (2013). Integrating culture into Vietnamese university EFL teaching: A critical ethnographic study. (Unpublished Doctoral Thesis). Auckland University of Technology, New Zealand.

Piatkowska, K. (2014). Fostering foreign language teachers' ability to teach intercultural communicate competence: A social constructivist perspective. International Journal of Arts \& Sciences, 7(6), 39-47.

Richards, J. (2005). Tactics for listening (2nd ed.). Oxford, UK: Oxford University Press.

Shi-xu (2006). Beyond competence: A multiculturalist approach to intercultural communication. In K. Bührig \& J. Thije (Eds.), Beyond misunderstanding: The linguistic reconstruction of intercultural communication (pp. 313-330). Amsterdam, Netherlands: John Benjamins Publishing Company.

Sun, L. (2013). Culture teaching in foreign language teaching. Theory and Practice in Language Studies, 3(2), 371-375.

Tran, T. Q., \& Duong, T. M. (2015). Intercultural language teaching: Rethinking the objectives of English language education in the Vietnamese context. English for Specific Purposes World, 46, 27-38.

Vo, Q. P. (2017). Rethinking intercultural communication competence in English language teaching: A gap between lecturers' perspectives and practices in a Southeast Asian tertiary context. I-Manager's Journal on English Language Teaching, 7(1), 20-29. 